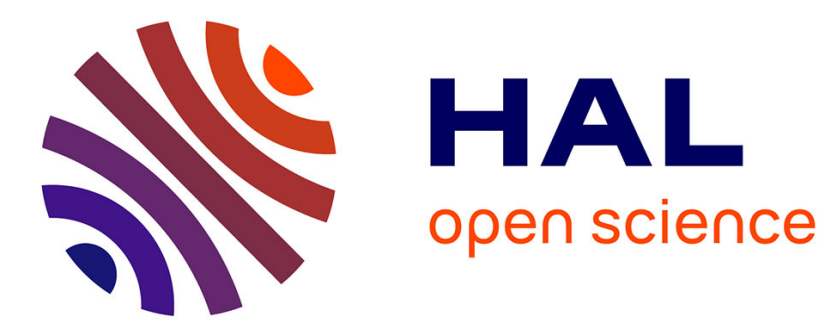

\title{
Differential Effects of IGF-I, IGF-II and Insulin in Human Preadipocytes and Adipocytes - Role of Insulin and IGF-I Receptors
}

Karolina Bäck, Cecilia Brännmark, Peter Strålfors, Hans J. Arnqvist

\section{- To cite this version:}

Karolina Bäck, Cecilia Brännmark, Peter Strålfors, Hans J. Arnqvist. Differential Effects of IGF-I, IGF-II and Insulin in Human Preadipocytes and Adipocytes - Role of Insulin and IGF-I Receptors. Molecular and Cellular Endocrinology, 2011, 10.1016/j.mce.2011.04.005 . hal-00708526

\section{HAL Id: hal-00708526 \\ https://hal.science/hal-00708526}

Submitted on 15 Jun 2012

HAL is a multi-disciplinary open access archive for the deposit and dissemination of scientific research documents, whether they are published or not. The documents may come from teaching and research institutions in France or abroad, or from public or private research centers.
L'archive ouverte pluridisciplinaire HAL, est destinée au dépôt et à la diffusion de documents scientifiques de niveau recherche, publiés ou non, émanant des établissements d'enseignement et de recherche français ou étrangers, des laboratoires publics ou privés. 


\section{Accepted Manuscript}

Title: Differential Effects of IGF-I, IGF-II and Insulin in Human Preadipocytes and Adipocytes - Role of Insulin and IGF-I Receptors

Authors: Karolina Bäck, Cecilia Brännmark, Peter Strålfors, Hans J. Arnqvist

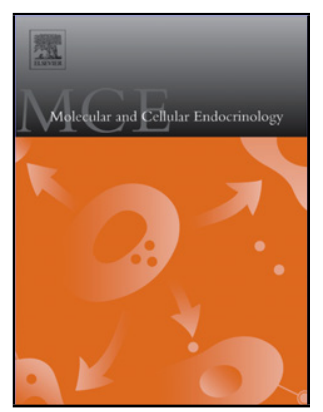

PII:

DOI:

Reference:

S0303-7207(11)00203-6

To appear in: $\quad$ Molecular and Cellular Endocrinology

Received date: $\quad 9-12-2010$

Revised date: $\quad 8-4-2011$

Accepted date: $\quad 8-4-2011$

Please cite this article as: Bäck, K., Brännmark, C., Strålfors, P., Arnqvist, H.J., Differential Effects of IGF-I, IGF-II and Insulin in Human Preadipocytes and Adipocytes - Role of Insulin and IGF-I Receptors, Molecular and Cellular Endocrinology (2010), doi:10.1016/j.mce.2011.04.005

This is a PDF file of an unedited manuscript that has been accepted for publication. As a service to our customers we are providing this early version of the manuscript. The manuscript will undergo copyediting, typesetting, and review of the resulting proof before it is published in its final form. Please note that during the production process errors may be discovered which could affect the content, and all legal disclaimers that apply to the journal pertain. 


\section{Differential Effects of IGF-I, IGF-II and Insulin in Human Preadipocytes and} Adipocytes - Role of Insulin and IGF-I Receptors

Karolina Bäck, Cecilia Brännmark, Peter Strålfors and Hans J Arnqvist

Linköping University, Department of Clinical and Experimental Medicine, Division of Cell Biology; and Linköping Diabetes Research Centre, Linköping, Sweden

Running title: IGF-I and IGF-II effects on insulin and IGF-I receptors

Corresponding author:

Karolina Bäck

Linköping University

Faculty of health sciences

Department of clinical and experimental medicine

Division of cell biology

S-581 85 Linköping

Sweden

Tel. +46101032789

Fax: +46101034273

E-mail address: karolina.back@liu.se

Keywords: growth factors, hybrid receptors, receptor activation, DNA synthesis, glucose metabolism 


\begin{abstract}
We compared insulin and IGF effects in adipocytes expressing IR (insulin receptors), and preadipocytes expressing IR and IGF-IR (IGF-I receptors).

Treatment of adipocytes with insulin, IGF-II or IGF-I resulted in phosphorylation of IR. Order of potency was insulin>IGF-II>IGF-I. In preadipocytes IR, IGF-IR and insulin/IGF-I hybrid receptors (HR) were detected. Treatment of preadipocytes with IGF-I and IGF-II $10^{-8} \mathrm{M}$ resulted in activation of IGF-IR and IR whereas insulin was more potent in activating IR, with no effect on IGF-IR.

In adipocytes glucose transport was 100-fold more sensitive to insulin than to IGFs and the maximal effect was higher with insulin. In preadipocytes glucose accumulation and DNA synthesis was equally sensitive to insulin and IGFs but the maximal effect was higher with IGF-I. In conclusion, insulin and IGF-I activate their cognate receptors and IGF-I also HR. IGF-II activates IR, IGF-IR and HR. Insulin and IGF-I are partial agonists to each other's receptors.
\end{abstract}




\section{Introduction}

Insulin, insulin-like growth factor-I (IGF-I) and insulin-like growth factor-II (IGF-II) are all part of the insulin-like growth factor family and involved in growth, metabolism and survival of the cell (Navarro et al., 1999; Saltiel,Kahn, 2001; Siddle et al., 2001; Chao,D'Amore, 2008). IGF-II is the predominant IGF in humans with circulating levels 5-10-fold higher than IGF-I (Frystyk, 2004; Hedman et al., 2004). In contrast to circulating IGF-I, which peaks during puberty, IGF-II is constantly expressed throughout life (Juul et al., 1995).

The IR and the IGF-IR are both members of the tyrosine kinase family of receptors and share an overall homology of more than 50\% (Ullrich et al., 1986). As a result of dissimilarities in structure there are differences in tyrosine phosphorylation of the receptors (Lammers et al., 1989). IGF-IR primarily mediates mitogenic effects, while IR primarily mediates metabolic effects (Blakesley et al., 1996; Kim,Accili, 2002). Differences in signalling between the two receptors can also be due to differences in distribution of the IR and IGF-IR in different cell types, receptor activation, rate of internalization and intracellular signal transduction (Blakesley et al., 1996; Kim,Accili, 2002; Werner et al., 2008). The $\alpha \beta$-heterodimers from IR and IGF-IR respectively can combine to form insulin/IGF-I hybrid receptors (Moxham et al., 1989). Insulin, IGF-I and IGF-II all bind to IGF-IR and IR but with different affinities, as reviewed by Werner et al (Werner et al., 2008). The IR has a high affinity for insulin, but can also bind IGF-II with 10-50 fold lower affinity and IGF-I with 100-500 fold lower affinity. IGF-II binds to the IGF-IR with 10-fold lower affinity compared with IGF-I. Insulin/IGF-I hybrid receptors function mainly as IGF-IR with much higher affinity for IGF-I and IGF-II than for insulin (Soos et al., 1993; Slaaby et al., 2006). This would imply that the effect of the ligand varies with different receptor distributions. 
Our aim was to compare the effects of insulin, IGF and IGF-II and study the impact of differences in distribution of IGF-IR and IR on their action in adipocytes, which express almost exclusively IR, and human preadipocytes, which express both of IR and IGF-IR (Bäck,Arnqvist, 2009).

\section{Materials and methods}

\subsection{Cell culture}

Cell culture flasks and plates were purchased from Corning (Schiphol-Rijk, The Netherlands) and all other cell culture materials were purchased from Invitrogen (Paisley, UK) or as indicated in the text. Human preadipocytes and adipocytes were isolated from subcutaneous adipose tissue from elective abdominal surgery. None of the patients had known diabetes. The average BMI was $26.7 \mathrm{~kg} / \mathrm{m}^{2}$, range $21.1-31.2 \mathrm{~kg} / \mathrm{m}^{2}$, except for one patient who was extremely obese, BMI $49.1 \mathrm{~kg} / \mathrm{m}^{2}$. All patients had given their informed consent, the procedures were approved by the local ethics committee at Linköping University and were performed in accordance with the Declaration of Helsinki.

\subsection{Isolation of human adipocytes and preadipocytes}

Fat pads were isolated and cut with scissors before incubation with $300 \mathrm{u} / \mathrm{ml}$ collagenase type 1 (Sigma-Aldrich Sweden AB, Stockholm, Sweden) in a Krebs-Ringer solution (0.12 M $\mathrm{NaCl}, 4.7 \mathrm{mM} \mathrm{KCl}, 1.2 \mathrm{mM} \mathrm{KH}_{2} \mathrm{PO}_{4}, 1.2 \mathrm{mM} \mathrm{MgSO}_{4}$ and $2.5 \mathrm{mM} \mathrm{CaCl}_{2}$ ) with addition of $20 \mathrm{mM}$ HEPES, pH 7.40, (Sigma), $2 \mathrm{mM}$ glucose, $200 \mathrm{nM}$ adenosine and 1\% (w/v) fatty acid-free bovine serum albumin (BSA). Digested tissue was filtered through gauze to remove connective tissue and cells were washed three times with the Krebs-Ringer solution. Fat cells 
were then isolated by flotation, a procedure which has been shown to give pure adipocytes (Rodbell, 1964). Isolated adipocytes were incubated in $37^{\circ} \mathrm{C}$ over night to reverse insulin resistance induced by surgical stress, as previously described in (Danielsson et al., 2005). Preadipocytes were isolated from the Krebs-Ringer solution after the adipocytes were removed by floatation essentially as described in (Halvorsen et al., 2001). Briefly, the cell suspension was centrifuged at 500xg for $5 \mathrm{~min}$ and the pellet washed once with preadipocyte culture medium (equal amounts of DMEM and Ham's F-12, 10\% (v/v) newborn calf serum (NCS), $100 \mathrm{iu} / \mathrm{ml}$ penicillin, $100 \mu \mathrm{g} / \mathrm{ml}$ streptomycin, $2 \mu \mathrm{g} / \mathrm{ml}$ Fungizone ${ }^{\circledR}$ ) and then cultured in $75 \mathrm{~cm}^{2}$ culture flasks with preadipocyte culture medium. Medium was changed 2-3 times a week and cells were passaged using trypsin-EDTA when nearly confluence. Cells were not used for more than 5 passages.

\subsection{Cell incubation}

Preadipocytes were serum-deprived over night in DMEM containing $100 \mathrm{iu} / \mathrm{ml}$ penicillin, 100 $\mu \mathrm{g} / \mathrm{ml}$ streptomycin, $2 \mu \mathrm{g} / \mathrm{ml}$ Fungizone ${ }^{\circledR}$ and $0.1 \%$ (w/v) BSA. Insulin, IGF-I or IGF-II at indicated concentrations were added to the flasks and they were incubated at $37^{\circ} \mathrm{C}$ for $10 \mathrm{~min}$. The medium was removed and lysis buffer ( $\mathrm{pH}$ 7.5) containing $20 \mathrm{mM}$ TrizmaBase, $150 \mathrm{mM}$ $\mathrm{NaCl}, 5 \mathrm{mM}$ EDTA, $0.5 \%(\mathrm{w} / \mathrm{v})$ sodiumdeoxycholate and $0.5 \%(\mathrm{v} / \mathrm{v})$ Triton X-100 with addition of $1 \mathrm{mM}$ phenylmethylsulphonyl fluoride (PMSF), $1.5 \mu \mathrm{g} / \mathrm{ml}$ leupeptin, $1 \mathrm{mM}$ $\mathrm{Na}_{3} \mathrm{VO}_{4}$ and $1.5 \mu \mathrm{g} / \mathrm{ml}$ aprotinin was added to the flasks. The cells were lysed on ice for 30 min and then harvested by scraping. The lysate was centrifuged at $12000 \mathrm{xg}$ for $15 \mathrm{~min}$ at $4^{\circ} \mathrm{C}$ and the supernatant was stored at $-70^{\circ} \mathrm{C}$ until use.

The adipocytes were preincubated for $15 \mathrm{~min}$ with $100 \mathrm{nM}$ phenylisopropyl adenosine and 0.5 $\mathrm{u} / \mathrm{ml}$ adenosine deaminase and then with indicated concentrations of insulin, IGF-I or IGF-II for a further $10 \mathrm{~min}$. The media were removed and the cells resuspended in the lysis buffer. 
The cells were homogenized using a potter-elvehjem grinder and the lysate was stored frozen until analyzed.

\subsection{Immunoprecipitation, SDS-PAGE and immunoblotting}

Lysates were immunoprecipitated (IP) with either rabbit polyclonal anti-IR $\beta$ antibody (c-19) or rabbit polyclonal anti-IGF-IR $\beta$ antibody (c-20) (Santa Cruz Biotechnology, Heidelberg, Germany), diluted 1:400, and incubated at $4^{\circ} \mathrm{C}$ for 2 h. $20 \mathrm{mg} / \mathrm{ml}$ Protein A Sepharose (GE Healthcare Bio-Sciences AB, Uppsala, Sweden) in 0.1\% (w/v) BSA in the lysis buffer was then added and the lysates were incubated overnight at $4^{\circ} \mathrm{C}$ with gentle rocking. The next day lysates were centrifuged at $6500 \mathrm{xg}$ for $5 \mathrm{~min}$, supernatants were removed and pellets were washed three times with the lysis buffer. Pellets were then dissolved in SDS-PAGE sample buffer (6.25 mM TrizmaBase, 1\% (w/v) SDS, 10\% (v/v) glycerol, 0.001\% (v/v) bromophenol) with addition of $2 \%(\mathrm{v} / \mathrm{v}) \beta$-mercaptoethanol and boiled for 3 minutes. Immunoprecipitated proteins were separated in $7.5 \%$ acrylamide gels and proteins electrophoretically blotted to polyvinylidene difluoride (PVDF) membranes. After blocking in $3 \%(\mathrm{w} / \mathrm{v})$ bovine serum albumin, membranes were incubated with antiphosphotyrosine (PY20) or, after stripping membranes in $62 \mathrm{mM}$ Tris-HCl, 2\% (w/v) sodium dodecylsulfate, $100 \mathrm{mM} \beta$-mercaptoethanol for 30 minutes at $56^{\circ} \mathrm{C}$, with anti-IGF-IR or anti-IR antibodies. Bound antibodies were detected using horseradish peroxidase-conjugated secondary antibodies and the ECL-plus kit of GE Healthcare. For densitometric evaluation autoradiographs were scanned with a LAS1000 camera (Fujifilm, Tokyo, Japan) and then analyzed using the Multi Gauge software, version 3.0 (Fujifilm). Protein phosphorylation was normalized to total receptor protein and data was expressed as $\%$ of maximum effect or as $\%$ of unstimulated control. 


\subsection{Determination of thymidine incorporation in preadipocytes}

Cultures of preadipocytes were grown in 6-well plates until near confluence. The cells were incubated with insulin and IGF-I at indicated concentrations in serum free DMEM overnight and then with $1 \mu \mathrm{Ci} / \mathrm{ml}\left[6{ }^{3} \mathrm{H}\right]$-thymidine for 3 hours at $37^{\circ} \mathrm{C}, 5 \% \mathrm{CO}_{2}$. Cells were washed and DNA was then precipitated in ice cold 5\% (w/v) trichloroacetic acid for $15 \mathrm{~min}$ at $4^{\circ} \mathrm{C}$. After treatment with $0.1 \mathrm{M}$ potassium hydroxide for 1-2 hours at room temperature $800 \mu \mathrm{l}$ of the lysate was added to $4 \mathrm{ml}$ of of UltimaGold ${ }^{\mathrm{TM}}$ scintillation fluid (Chemical Instruments $\mathrm{AB}$ (CiAB), Sollentuna, Sweden) and the radioactivity was measured. Data were expressed as percent of radioactivity in untreated control cells.

\subsection{Determination of glucose accumulation in preadipocytes}

Glucose accumulation was determined as described previously (Bäck,Arnqvist, 2009). Briefly, the cells were grown in 6-well plates, serum-deprived overnight and then incubated for $3 \mathrm{~h}$ in serum free DMEM (glucose concentration $1000 \mathrm{mg} / \mathrm{l}$ ) with addition of $0.2 \mu \mathrm{Ci} / \mathrm{ml}$ D-[U- $\left.{ }^{14} \mathrm{C}\right]$-glucose and insulin or IGF-I at indicated concentrations. The cells were lysed in $0.1 \%$ sodium dodecylsulfate and the radioactivity was measured. Data were expressed as percent of radioactivity in unstimulated control cells. $\mathrm{EC}_{50}$ values, maximum values and confidence intervals were calculated with GraphPad Prism 4.00 (GraphPad Software Inc., San Diego, CA, USA).

\subsection{Determination of glucose transport in adipocytes}

Glucose uptake was determined as uptake of 2-deoxy-D-[1- $\left.{ }^{3} \mathrm{H}\right]$ glucose (Amersham Biotech, Uppsala, Sweden) after transfer of cells to medium without glucose (Karlsson et al., 2004). Adipocytes at $10 \%(\mathrm{v} / \mathrm{v})$ were incubated at $37^{\circ} \mathrm{C}$ with the indicated concentration of insulin, IGF-I or IGF-II for $15 \mathrm{~min}$, when 2-deoxy-D-[1- $\left.{ }^{3} \mathrm{H}\right]$ glucose was added to a final 
concentration of $50 \mu \mathrm{M}(10 \mu \mathrm{Ci} / \mathrm{mL})$ and the cells were incubated for a further $30 \mathrm{~min}$. Incubations were terminated by separating the cells from the medium during 5-second centrifugation through dinonylphtalate oil. The cell cake was dissolved in sodium dodecyl sulfate (SDS) and the amount of radioactivity in the cells determined by scintillation counting. Radioactivity in the medium trapped between cells was corrected for by subtracting radioactivity in incubations that were immediately terminated by addition of cytochalasin $\mathrm{B}$ and spinning through the oil. $\mathrm{EC}_{50}$ values, maximum values and confidence intervals were calculated with GraphPad Prism 4.00 (GraphPad Software Inc., San Diego, CA, USA).

\subsection{Statistical analysis}

Statistical comparisons were made with SPSS 17.0 (SPSS Inc. Headquarters, Chicago, Illinois, USA) by ANOVA. For post hoc analysis Dunnet's test was used. When indicated a nonparametric test, related-samples Wilcoxson signed ranks test, was used. GraphPad Prism 4.00 (GraphPad Software Inc., San Diego, CA, USA) was used for comparison of dose response curves when indicated, and for drawing bar graphs. A $p$ value $<0.05$ was considered statistically significant. Data is presented as mean \pm SE.

\section{Results}

\subsection{Preadipocytes}

\subsubsection{Receptor phosphorylation}


In preadipocytes we detected IGF-IR after immunoprecipitation with IR antibody and then immunoblotting with an IGF-IR antibody, and vice versa, indicating the presence of insulin/IGF-I hybrid receptors.

Preadipocytes were stimulated with either IGF-II, IGF-I or insulin at $10^{-9}-10^{-8} \mathrm{M}$ (Figure 1), then the receptor proteins were immunoprecipitated either with an antibody against the IGFIR $\beta$-subunit or with an antibody against the IR $\beta$-subunit and analyzed by SDS-PAGE and immunoblotting. After immunoprecipitation with the antibody against IGF-IR $\beta$ we could detect phosphorylation by IGF-II $10^{-8} \mathrm{M}$, IGF-I $10^{-8} \mathrm{M}$, inconsistently also by IGF-I $10^{-9} \mathrm{M}$, but not by insulin. Immunoprecipitation with the antibody against IR $\beta$ revealed phosphorylation by IGF-II $10^{-8} \mathrm{M}$, insulin $10^{-9}-10^{-8} \mathrm{M}$ and IGF-I $10^{-8} \mathrm{M}$.

\subsubsection{Thymidine incorporation}

To quantify DNA synthesis in preadipocytes the incorporation of $\left[6-{ }^{3} \mathrm{H}\right]$-thymidine was examined after the cells were stimulated with insulin, IGF-I or IGF-II at $10^{-11}-10^{-7} \mathrm{M}$ (Figure 2A). IGF-I $10^{-8} \mathrm{M}$, IGF-II $10^{-8} \mathrm{M}$ or IGF-I $10^{-7} \mathrm{M}$ significantly stimulated DNA synthesis. The effect of IGF-I tended to be higher than that of insulin.

To further examine the higher maximal effects of IGF-I compared to insulin a new set of experiments were performed to see if the effect of IGF-I was additional to the effect of insulin. Cells were treated with insulin $10^{-8}-10^{-5} \mathrm{M}$ alone or with IGF-I $10^{-8}$ or $10^{-7} \mathrm{M}$ added (Figure 2B). As seen in Figure 2A a maximal effect of IGF-I alone was obtained at a concentration of $10^{-8} \mathrm{M}$ and did not increase further at $10^{-7} \mathrm{M}$. With insulin alone a maximal effect was obtained at $10^{-6} \mathrm{M}$ and then levelled off.

The addition of IGF-I at the concentration of either $10^{-8}$ or $10^{-7}$ both resulted in an additional effect compared to insulin alone (Figure 2B). To compare the maximal effects the peak of each curve was compared to the other's in each experiment. Using paired t-test a p-value of 
0.059 was found and when using related-samples Wilcoxson signed ranks test, a nonparametric test, a significant difference $(\mathrm{p}=0.046)$ was found between the highest effect of insulin alone $\left(10^{-6} \mathrm{M}\right)$ and the highest effect of insulin + IGF-I $10^{-8} \mathrm{M}$ obtained at insulin $10^{-7}$ M. At insulin concentrations above $10^{-7} \mathrm{M}$ the effect of adding IGF-I, either $10^{-8} \mathrm{M}$ or $10^{-7} \mathrm{M}$, started to decrease.

\subsubsection{Glucose accumulation}

The accumulation of $\mathrm{D}-\left[\mathrm{U}_{-}{ }^{14} \mathrm{C}\right]$-glucose was investigated to examine the metabolic effects of IGF-II, insulin and IGF-I in preadipocytes (Figure 3). The cells were stimulated with IGF-II, insulin or IGF-I at $10^{-11}-10^{-7} \mathrm{M}$. IGF-II $10^{-8}-10^{-7} \mathrm{M}$, insulin $10^{-8}-10^{-7} \mathrm{M}$ or IGF-I $10^{-9}-10^{-7} \mathrm{M}$ significantly stimulated glucose accumulation in comparison with unstimulated controls. The $\mathrm{EC}_{50}$ values were similar for all three conditions, $1.29 \times 10^{-9} \pm 0.24 \times 10^{-9} \mathrm{M}$ for IGF-II, $0.89 \times 10^{-}$ ${ }^{9} \pm 0.03 \times 10^{-9} \mathrm{M}$ for insulin, and $0.73 \times 10^{-9} \pm 0.03 \times 10^{-9} \mathrm{M}$ for IGF-I. However, the maximal response obtained by IGF-I was higher than the responses obtained by IGF-II or insulin. The max effects and $95 \%$ confidence interval for the max effects (expressed as percent above control) were for IGF-II 79.4 (63.9-94.8), for IGF-I 104.9 (85.1-124.8) and for insulin 59.3 (46.0-72.6).

\subsection{Adipocytes}

\subsubsection{Receptor phosphorylation}

Adipocytes were stimulated with insulin at $10^{-9}-10^{-8} \mathrm{M}$, or IGF-I or IGF-II at $10^{-9}-10^{-7} \mathrm{M}$ (Figure 4). Receptor proteins were then immunoprecipitated and analyzed with SDS-PAGE and immunoblotting. 
IGF-IR protein was barely demonstrable and phosphorylation of the IGF-IR could not be detected. The IR was phosphorylated in response to IGF-I at $10^{-7} \mathrm{M}$, IGF-II at $10^{-8}-10^{-7} \mathrm{M}$, insulin at $10^{-9}-10^{-8} \mathrm{M}$, and inconsistently by IGF-I at $10^{-8} \mathrm{M}$.

\subsubsection{Glucose transport}

We examined glucose uptake in response to insulin, IGF-I or IGF-II in order to investigate the metabolic effects of these stimuli on human adipocytes (Figure 5). IGF-II had an $\mathrm{EC}_{50}$ value of $3 \times 10^{-9} \mathrm{M}$, the $\mathrm{EC}_{50}$ value of insulin was $20 \times 10^{-12} \mathrm{M}$ and for IGF-I it was $6 \times 10^{-9} \mathrm{M}$. The max effects and $95 \%$ confidence interval for the max effects (expressed as percent above control) were for IGF-II 95.8 (18.7-172.9), IGF-I 87.0 (74.1-99.9) and for insulin 139.9 (103.8-176.0).

\section{Discussion}

We recently showed that human adipocytes contain very few IGF-IRs in comparison to IRs, whereas human preadipocytes exhibit both receptors (Bäck,Arnqvist, 2009). This gives an opportunity to study the impact of differences in receptor distribution on the effects of insulin and IGFs. In this study adipocyte IGF-IR protein was barely demonstrable and phosphorylation of IGF-IR was not detected. In preadipocytes IGF-II at $10^{-8} \mathrm{M}$ activated both the IR and IGF-IR. To our knowledge effects of IGF-II on human preadipocytes have not been reported before. It should be noted that the IR exists in two isoforms due to alternative splicing of the IR gene. Isoform B contains the 12 amino acids encoded by the exon that has been spliced off in isoform A. IGF-II has a higher affinity for IR-A than for IR-B (Belfiore et al., 2009). In adipose tissue both IR-A and IR-B are present (Sesti et al., 1995). We have 
recently shown that isolated adipocytes express mostly IR-A and few IR-B, while preadipocytes express only IR-A (Bäck,Arnqvist, 2009).

No effect of insulin at $10^{-9}-10^{-8} \mathrm{M}$ was found on the phosphorylation of IGF-IR in preadipocytes, but insulin is known to phosphorylate the IGF-IR at higher concentrations (Chisalita et al., 2006). The IR in preadipocytes was phosphorylated in response to insulin at physiological concentrations $\left(10^{-9}-10^{-8} \mathrm{M}\right)$. IGF-I at $10^{-8} \mathrm{M}$ activated the IR in preadipocytes but not in adipocytes. After immunoprecipitation with antibodies specific for the IGF-IR $\beta$ subunit we could detect both the IGF-IR $\beta$-subunit and the IR $\beta$-subunit on the gel and after immunoprecipitation with antibodies specific for the IR $\beta$-subunit we could detect both the IR $\beta$-subunit and the IGF-IR $\beta$-subunit. In mature adipocytes only antibodies specific for the IR $\beta$-subunit precipitated the IR $\beta$-subunit and no IGF-IR $\beta$-subunit was detected on the gel. This shows that some of the receptors on preadipocytes, but not on adipocytes, are insulin/IGF-I hybrid receptors. Hybrid receptors have been reported to function as IGF-IR thus having a high affinity for IGF-I but not for insulin (Soos et al., 1993). The fact that the IR $\beta$-subunit immunoprecipitated with antibodies against the IGF-IR was not activated by insulin (Figure 1) and that the IR was activated by IGF-I $10^{-8} \mathrm{M}$ in preadipocytes but not in adipocytes is probably explained by insulin/IGF-I hybrid receptors (Frattali,Pessin, 1993; Engberding et al., 2009).

Glucose uptake in preadipocytes tended to increase at $10^{-9} \mathrm{M}$ insulin and was significantly stimulated at $10^{-8}-10^{-7} \mathrm{M}$ with an $\mathrm{EC}_{50}$ value of $0.9 \times 10^{-9} \mathrm{M}$. As preadipocytes mainly express glucose transporter-1 (GLUT1) and not the insulin-regulated GLUT4 (Hauner et al., 1998; Bäck,Arnqvist, 2009), these effects of insulin in the preadipocytes could be due to relocation of GLUT1 in combination with enhanced metabolism of glucose. IGF-I or IGF-II stimulated glucose uptake with similar $\mathrm{EC}_{50}$ values as insulin, $0.7 \times 10^{-9} \mathrm{M}$ and $1.3 \times 10^{-9} \mathrm{M}$, respectively. 
IGF-I, IGF-II and insulin also stimulated DNA synthesis in a similar way. With regard to the metabolic and mitogenic effects preadipocytes exhibit similar sensitivity for IGF-I, IGF-II and insulin. Although comparable effects of insulin, IGF-I and IGF-II were found in mitogenic and metabolic assays the initiation of the effects were probably different. Judging from the receptor phosphorylation assays, insulin activated IR, IGF-I activated IGF-IR and insulin/IGF-I hybrid receptors while IGF-II activated IR, IGF-IR and insulin/IGF-I hybrid receptors. Our experiments do not allow us to conclude which insulin receptor isoform that is involved in the IGF-II effects in preadipocytes.

In adipocytes the stimulation of glucose transport was about 100 -fold more sensitive to the action of insulin than to the effects of IGF-I and IGF-II. EC Ev $_{50}$ values for adipocytes glucose accumulation, observed by Sinha et al (Sinha et al., 1989; Sinha et al., 1990), were $3 \times 10^{-11}$ $6 \times 10^{-11} \mathrm{M}$ for insulin, $2 \times 10^{-9} \mathrm{M}$ for IGF-II and $2 \times 10^{-8} \mathrm{M}$ for IGF-I. This is well in agreement with our results $\left(2 \times 10^{-11} \mathrm{M}\right.$ for insulin, $3 \times 10^{-9} \mathrm{M}$ for IGF-II and $0.6 \times 10^{-8} \mathrm{M}$ for IGF-I). IGF-II is known to have a higher affinity for IR than IGF-I (Denley et al., 2004) and in our study IR was phosphorylated at a 10-fold lower concentration of IGF-II than of IGF-I. Our study shows that when preadipocytes are developed into mature adipocytes there is a huge increase in their response to insulin. This suggests that the recruitment of preadipocytes into adipocytes is a critical step in the regulation of adiposity.

In preadipocytes the maximal effects of IGF-I on glucose accumulation and DNA synthesis were higher than the maximal effect of insulin. When studied on thymidine incorporation in preadipocytes IGF-I in combination with insulin gave an additional effect compared to the maximal effect of insulin alone. This suggests that insulin is only a partial agonist to the IGFIR and insulin/IGF-I hybrid receptor, and that IGF-I has other properties than insulin when 
interacting with its cognate receptor, which could possibly be of importance in malignancies (Frasca et al., 2008). An augmented mitogenic effect of IGF-I compared to insulin has also been observed in vascular smooth muscle cells (Bornfeldt et al., 1991) and in cultured human skeletal muscle IGF-I has an increased mitogenic activity compared with insulin (Ciaraldi et al., 2001). It is believed that the C-domain of IGF-I somehow is important for interaction with the IGF-I receptor as suggested by Denley (Denley et al., 2004) and that this may in part explain the differences in maximal effects between IGF-I and insulin. Another very potent activator of mitogenic signalling via the IGF-IR is IGF-II. However IGF-II does not interact with the CR-domain of the IGF-IR and it is therefore likely that other structural determinants of the IGF-IR are of importance for mitogenic signalling (Ward,Lawrence, 2009). There are also other differences in the interaction of IGF-I with the IGF-IR or IR which affect binding affinity and influence signalling (De Meyts, Whittaker, 2002; Ward,Lawrence, 2009). In human adipocytes the maximal effect of insulin on glucose transport was significantly higher than the effects of IGF-I. There are few comparisons of maximal effects of insulin and IGFs in adipocytes in the literature and the results are not conclusive (DiGirolamo et al., 1986; Bolinder et al., 1987; Sinha et al., 1989).

When thymidine incorporation was studied with high concentrations of ligand the effect levelled off. This was seen with insulin alone and with IGF-I added to insulin. This may be explained by negative cooperativity (De Meyts, Whittaker, 2002). It is also possible that high concentrations of stimuli may induce negative feedback signals (Danielsson et al., 2006).

In conclusion our results suggest that insulin and IGF-I activate their cognate receptors and IGF-I also insulin/IGF-I hybrid receptors whereas IGF-II at physiological concentrations can activate both insulin and IGF-I receptors as well as insulin/IGF-I hybrid receptors. Insulin and IGF-I are only partial agonists to each other's receptors. 


\section{Declaration of interest}

The authors declare that there is no conflict of interest.

\section{Funding}

This work was supported by Landstinget Östergötland, Barndiabetesfonden and the Swedish Research Council (PS).

\section{Acknowledgements}

We thank Anna-Kristina Granath for excellent technical assistance. 


\section{References}

Belfiore, A., Frasca, F., Pandini, G., Sciacca, L.Vigneri, R., 2009. Insulin receptor isoforms and insulin receptor/insulin-like growth factor receptor hybrids in physiology and disease. Endocr Rev. 30, 6: 586-623.

Blakesley, V. A., Scrimgeour, A., Esposito, D.Le Roith, D., 1996. Signaling via the insulinlike growth factor-I receptor: does it differ from insulin receptor signaling? Cytokine Growth Factor Rev. 7, 2: 153-9.

Bolinder, J., Lindblad, A., Engfeldt, P.Arner, P., 1987. Studies of acute effects of insulin-like growth factors I and II in human fat cells. J Clin Endocrinol Metab. 65, 4: 732-7.

Bornfeldt, K. E., Gidlof, R. A., Wasteson, A., Lake, M., Skottner, A.Arnqvist, H. J., 1991. Binding and biological effects of insulin, insulin analogues and insulin-like growth factors in rat aortic smooth muscle cells. Comparison of maximal growth promoting activities. Diabetologia. 34, 5: 307-13.

Bäck, K.Arnqvist, H. J., 2009. Changes in insulin and IGF-I receptor expression during differentiation of human preadipocytes. Growth Horm IGF Res. 19, 2: 101-11.

Chao, W.D'Amore, P. A., 2008. IGF2: epigenetic regulation and role in development and disease. Cytokine Growth Factor Rev. 19, 2: 111-20.

Chisalita, S. I., Nitert, M. D.Arnqvist, H. J., 2006. Characterisation of receptors for IGF-I and insulin; evidence for hybrid insulin/IGF-I receptor in human coronary artery endothelial cells. Growth Horm IGF Res. 16, 4: 258-66.

Ciaraldi, T. P., Carter, L., Seipke, G., Mudaliar, S.Henry, R. R., 2001. Effects of the longacting insulin analog insulin glargine on cultured human skeletal muscle cells: comparisons to insulin and IGF-I. J Clin Endocrinol Metab. 86, 12: 5838-47. 
Danielsson, A., Nystrom, F. H.Stralfors, P., 2006. Phosphorylation of IRS1 at serine 307 and serine 312 in response to insulin in human adipocytes. Biochem Biophys Res Commun. 342, 4: 1183-7.

Danielsson, A., Öst, A., Lystedt, E., Kjolhede, P., Gustavsson, J., Nyström, F. H.Strålfors, P., 2005. Insulin resistance in human adipocytes occurs downstream of IRS1 after surgical cell isolation but at the level of phosphorylation of IRS1 in type 2 diabetes. FEBS J. 272, 1: 141-51.

De Meyts, P.Whittaker, J., 2002. Structural biology of insulin and IGF1 receptors: implications for drug design. Nat Rev Drug Discov. 1, 10: 769-83.

Denley, A., Bonython, E. R., Booker, G. W., Cosgrove, L. J., Forbes, B. E., Ward, C. W.Wallace, J. C., 2004. Structural determinants for high-affinity binding of insulinlike growth factor II to insulin receptor (IR)-A, the exon 11 minus isoform of the IR. Mol Endocrinol. 18, 10: 2502-12.

DiGirolamo, M., Eden, S., Enberg, G., Isaksson, O., Lonnroth, P., Hall, K.Smith, U., 1986. Specific binding of human growth hormone but not insulin-like growth factors by human adipocytes. FEBS Lett. 205, 1: 15-9.

Engberding, N., San Martin, A., Martin-Garrido, A., Koga, M., Pounkova, L., Lyons, E., Lassegue, B.Griendling, K. K., 2009. Insulin-like growth factor-1 receptor expression masks the antiinflammatory and glucose uptake capacity of insulin in vascular smooth muscle cells. Arterioscler Thromb Vasc Biol. 29, 3: 408-15.

Frasca, F., Pandini, G., Sciacca, L., Pezzino, V., Squatrito, S., Belfiore, A.Vigneri, R., 2008. The role of insulin receptors and IGF-I receptors in cancer and other diseases. Arch Physiol Biochem. 114, 1: 23-37. 
Frattali, A. L.Pessin, J. E., 1993. Relationship between alpha subunit ligand occupancy and beta subunit autophosphorylation in insulin/insulin-like growth factor-1 hybrid receptors. J Biol Chem. 268, 10: 7393-400.

Frystyk, J., 2004. Free insulin-like growth factors -- measurements and relationships to growth hormone secretion and glucose homeostasis. Growth Horm IGF Res. 14, 5: $337-75$.

Halvorsen, Y. D., Bond, A., Sen, A., Franklin, D. M., Lea-Currie, Y. R., Sujkowski, D., Ellis, P. N., Wilkison, W. O.Gimble, J. M., 2001. Thiazolidinediones and glucocorticoids synergistically induce differentiation of human adipose tissue stromal cells: biochemical, cellular, and molecular analysis. Metabolism. 50, 4: 407-13.

Hauner, H., Rohrig, K., Spelleken, M., Liu, L. S.Eckel, J., 1998. Development of insulinresponsive glucose uptake and GLUT4 expression in differentiating human adipocyte precursor cells. Int J Obes Relat Metab Disord. 22, 5: 448-53.

Hedman, C. A., Frystyk, J., Lindström, T., Chen, J. W., Flyvbjerg, A., Orskov, H.Arnqvist, H. J., 2004. Residual beta-cell function more than glycemic control determines abnormalities of the insulin-like growth factor system in type 1 diabetes. J Clin Endocrinol Metab. 89, 12: 6305-9.

Juul, A., Dalgaard, P., Blum, W. F., Bang, P., Hall, K., Michaelsen, K. F., Muller, J.Skakkebaek, N. E., 1995. Serum levels of insulin-like growth factor (IGF)-binding protein-3 (IGFBP-3) in healthy infants, children, and adolescents: the relation to IGFI, IGF-II, IGFBP-1, IGFBP-2, age, sex, body mass index, and pubertal maturation. J Clin Endocrinol Metab. 80, 8: 2534-42.

Karlsson, M., Thorn, H., Danielsson, A., Stenkula, K. G., Öst, A., Gustavsson, J., Nyström, F. H.Strålfors, P., 2004. Colocalization of insulin receptor and insulin receptor substrate- 
1 to caveolae in primary human adipocytes. Cholesterol depletion blocks insulin signalling for metabolic and mitogenic control. Eur J Biochem. 271, 12: 2471-9.

Kim, J. J.Accili, D., 2002. Signalling through IGF-I and insulin receptors: where is the specificity? Growth Horm IGF Res. 12, 2: 84-90.

Lammers, R., Gray, A., Schlessinger, J.Ullrich, A., 1989. Differential signalling potential of insulin- and IGF-1-receptor cytoplasmic domains. Embo J. 8, 5: 1369-75.

Moxham, C. P., Duronio, V.Jacobs, S., 1989. Insulin-like growth factor I receptor betasubunit heterogeneity. Evidence for hybrid tetramers composed of insulin-like growth factor I and insulin receptor heterodimers. J Biol Chem. 264, 22: 13238-44.

Navarro, I., Leibush, B., Moon, T. W., Plisetskaya, E. M., Banos, N., Mendez, E., Planas, J. V.Gutierrez, J., 1999. Insulin, insulin-like growth factor-I (IGF-I) and glucagon: the evolution of their receptors. Comp Biochem Physiol B Biochem Mol Biol. 122, 2: 137-53.

Rodbell, M., 1964. Metabolism of Isolated Fat Cells. I. Effects of Hormones on Glucose Metabolism and Lipolysis. J Biol Chem. 239: 375-80.

Saltiel, A. R.Kahn, C. R., 2001. Insulin signalling and the regulation of glucose and lipid metabolism. Nature. 414, 6865: 799-806.

Sesti, G., D'Alfonso, R., Vargas Punti, M. D., Frittitta, L., Trischitta, V., Liu, Y. Y., Borboni, P., Longhi, R., Montemurro, A.Lauro, R., 1995. Peptide-based radioimmunoassay for the two isoforms of the human insulin receptor. Diabetologia. 38, 4: 445-53.

Siddle, K., Urso, B., Niesler, C. A., Cope, D. L., Molina, L., Surinya, K. H.Soos, M. A., 2001. Specificity in ligand binding and intracellular signalling by insulin and insulin-like growth factor receptors. Biochem Soc Trans. 29, Pt 4: 513-25.

Sinha, M. K., Buchanan, C., Leggett, N., Martin, L., Khazanie, P. G., Dimarchi, R., Pories, W. J.Caro, J. F., 1989. Mechanism of IGF-I-stimulated glucose transport in human 
adipocytes. Demonstration of specific IGF-I receptors not involved in stimulation of glucose transport. Diabetes. 38, 10: 1217-25.

Sinha, M. K., Buchanan, C., Raineri-Maldonado, C., Khazanie, P., Atkinson, S., DiMarchi, R.Caro, J. F., 1990. IGF-II receptors and IGF-II-stimulated glucose transport in human fat cells. Am J Physiol. 258, 3 Pt 1: E534-42.

Slaaby, R., Schaffer, L., Lautrup-Larsen, I., Andersen, A. S., Shaw, A. C., Mathiasen, I. S.Brandt, J., 2006. Hybrid receptors formed by insulin receptor (IR) and insulin-like growth factor I receptor (IGF-IR) have low insulin and high IGF-1 affinity irrespective of the IR splice variant. J Biol Chem. 281, 36: 25869-74.

Soos, M. A., Field, C. E.Siddle, K., 1993. Purified hybrid insulin/insulin-like growth factor-I receptors bind insulin-like growth factor-I, but not insulin, with high affinity. Biochem J. 290 ( Pt 2): 419-26.

Ullrich, A., Gray, A., Tam, A. W., Yang-Feng, T., Tsubokawa, M., Collins, C., Henzel, W., Le Bon, T., Kathuria, S., Chen, E., Jacobs, S., Francke, U., Ramachandran, J.FujitaYamaguchi, Y., 1986. Insulin-like growth factor I receptor primary structure: comparison with insulin receptor suggests structural determinants that define functional specificity. Embo J. 5, 10: 2503-12.

Ward, C. W.Lawrence, M. C., 2009. Ligand-induced activation of the insulin receptor: a multi-step process involving structural changes in both the ligand and the receptor. Bioessays. 31, 4: 422-34.

Werner, H., Weinstein, D.Bentov, I., 2008. Similarities and differences between insulin and IGF-I: structures, receptors, and signalling pathways. Arch Physiol Biochem. 114, 1: $17-22$. 


\section{Figure legends}

\section{Figure 1}

Phosphorylation of IGF-IR and IR in human preadipocytes. Cell lysate was immunoprecipitated (IP) with polyclonal antibodies against either the IGF-I receptor (IGF-IR) $\beta$-subunit (c-20) (A-B) or the insulin receptor (IR) $\beta$-subunit (c-19) (C-D). Immunoblotting with a phosphotyrosine antibody (PY-20) was used to analyze the phosphorylation. Results are mean \pm SE from 3-6 separate experiments with preadipocytes from different subjects. ${ }^{*} p<0.05$ in comparison with unstimulated control. $*^{*} p<0.001$ in comparison with unstimulated control.

\section{Figure 2}

(A) Effects of IGF-II (gray bars), insulin (white bars) and IGF-I (black bars) on the incorporation of $\left[6-{ }^{3} \mathrm{H}\right]$-thymidine in human preadipocytes. Near confluent cells were stimulated with peptides in serum-free DMEM over night and then incubated with $\left[6-{ }^{3} \mathrm{H}\right]-$ thymidine for $3 \mathrm{~h}$. Results are mean \pm SE from 6 separate experiments with preadipocytes from different subjects. ${ }^{*} p<0.05$ in comparison with unstimulated control. ${ }^{* *} p<0.001$ in comparison with unstimulated control.

(B) Effects of insulin (white bars), insulin + IGF-I $10^{-8}$ (gray bars) or insulin + IGF-I $10^{-7}$ (black bars) on the incorporation of $\left[6-{ }^{3} \mathrm{H}\right]$-thymidine in human preadipocytes. Near confluent cells were stimulated with peptides in serum-free DMEM over night and then incubated with $\left[6-{ }^{3} \mathrm{H}\right]$-thymidine for $3 \mathrm{~h}$. Results are mean \pm SE from 6 separate experiments with preadipocytes from different subjects.

\section{Figure 3}


Effects of IGF-II $(\boldsymbol{\bullet})$, IGF-I $(\boldsymbol{\Delta})$ and insulin $(\bullet)$ on the accumulation of D-[U- $\left.{ }^{14} \mathrm{C}\right]$-glucose in human preadipocytes. Near confluent cells were incubated at $37^{\circ} \mathrm{C}$ for $3 \mathrm{~h}$ with $\mathrm{D}-\left[\mathrm{U}-{ }^{14} \mathrm{C}\right]-$ glucose and polypeptides.

Results are mean \pm SE from 6 separate experiments with preadipocytes from different subjects. ${ }^{*} p<0.05$ in comparison with unstimulated control. ${ }^{*} p<0.001$ in comparison with unstimulated control.

\section{Figure 4}

Phosphorylation of IR in human adipocytes. Cell lysate was immunoprecipitated (IP) with polyclonal antibodies against the insulin receptor (IR) $\beta$-subunit (c-19). Immunoblotting with a phosphotyrosine antibody (PY-20) was used to analyze the phosphorylation. Cells were stimulated with insulin, IGF-I or IGF-II at $10^{-9}, 10^{-8}$ (A) or $10^{-7}(\mathrm{C}) \mathrm{M}$. Gels were analysed densitometrically (B). Results are mean \pm SE from 3 separate experiments. Adipocytes isolated from the same individual were used for control and stimulation by the ligand (IGF-I, IGF-II or insulin). To get enough material adipocytes from all in all 10 different patients had to be used. ${ }^{*} p<0.05$ in comparison with unstimulated control.

\section{Figure 5}

Primary human adipocytes was incubated with the indicated concentrations of IGF-II ( $\square$ ),

IGF-I ( $\boldsymbol{\Delta}$ ) or insulin $(\bullet)$ for $15 \mathrm{~min}$ and the glucose transport was determined as the uptake of 2-deoxy-D- $\left[1-{ }^{3} \mathrm{H}\right]$ glucose. Results are expressed as $\%$ above unstimulated control, mean of 5 (insulin) or 4 (IGF-I and IGF-II) subjects \pm SE. $* p<0.05$ in comparison with unstimulated control. $* * p<0.001$ in comparison with unstimulated control. 


\section{Highlights}

In preadipocytes IR, IGF-IR and insulin/IGF-I hybrid receptors were detected. Insulin and IGF-I activate their cognate receptors and IGF-I also hybrid receptors. IGF-II activates IR, IGF-IR and insulin/IGF-I hybrid receptors.

Insulin and IGF-I are partial agonists to each other's receptors. 
A

IP: IGF-IR

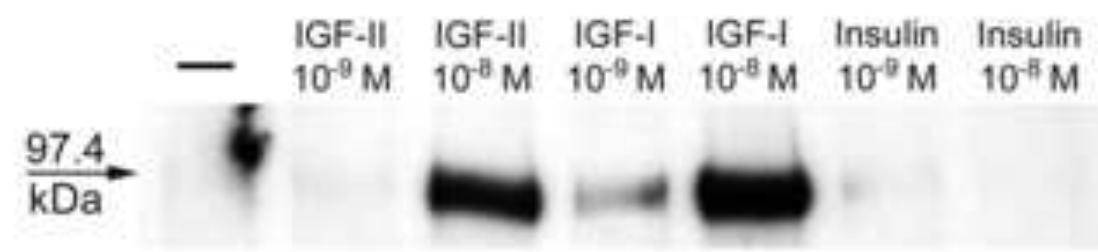

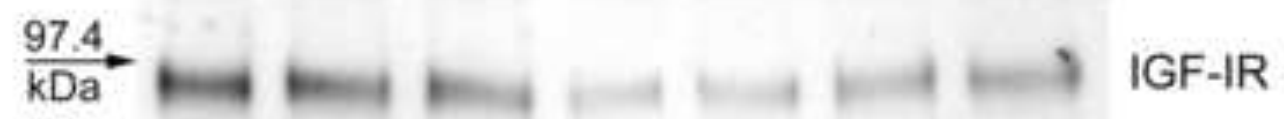

$\frac{97.4}{\mathrm{kDa}}=$ IR

C

IP: IR

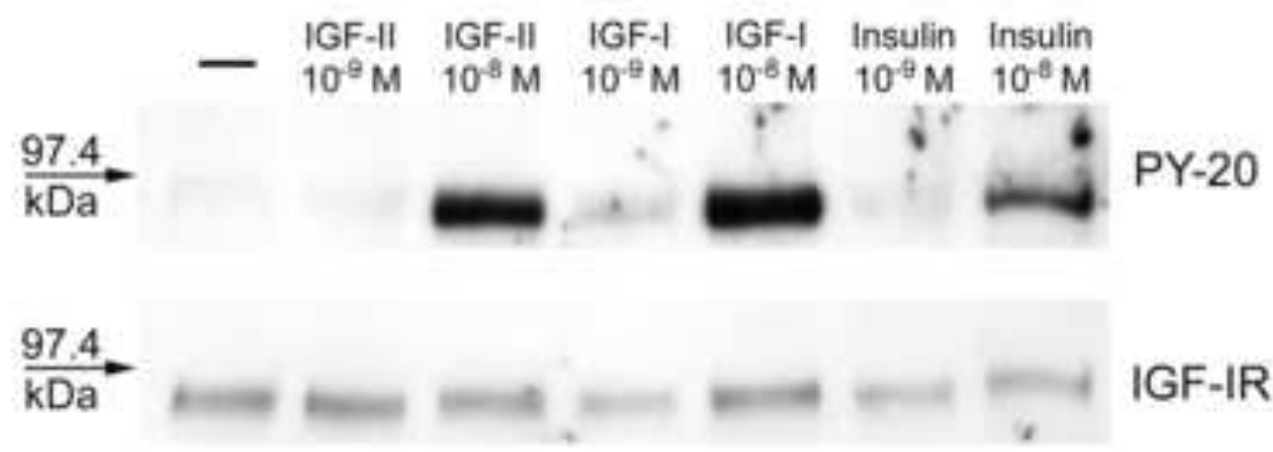

$\underset{\mathrm{kDa}}{97.4}$
B

IP: IGF-IR

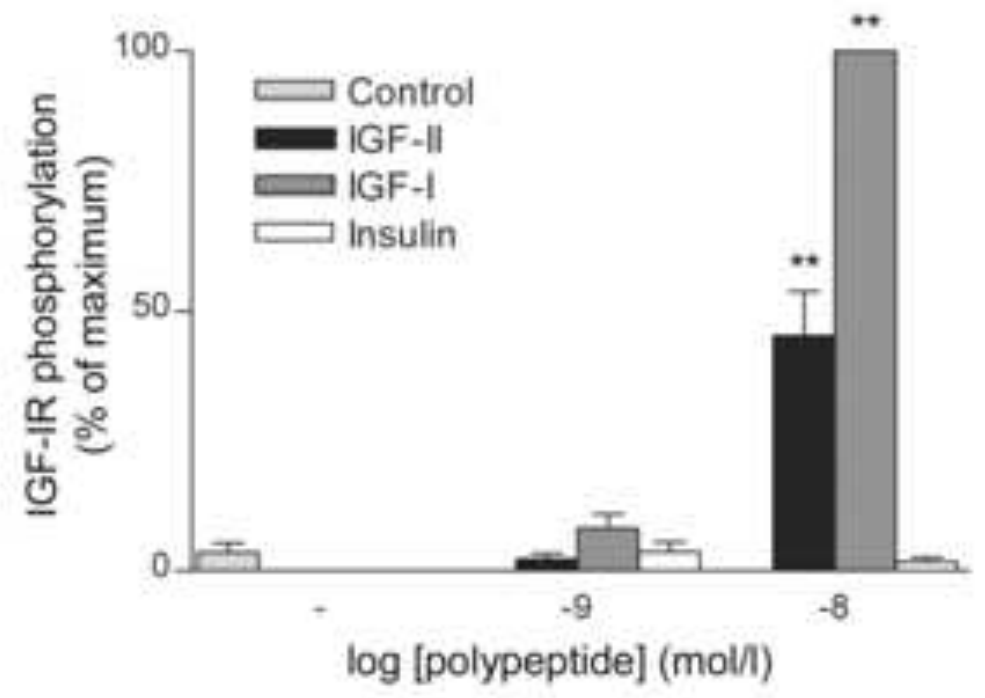

D

IP: IR

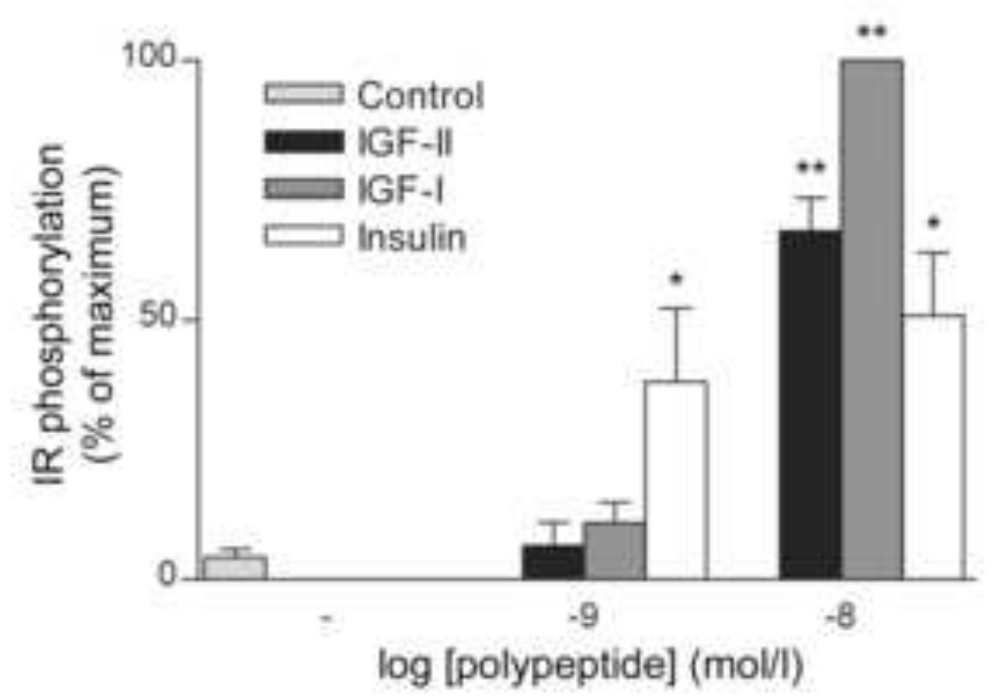

rage 24 ot 28 


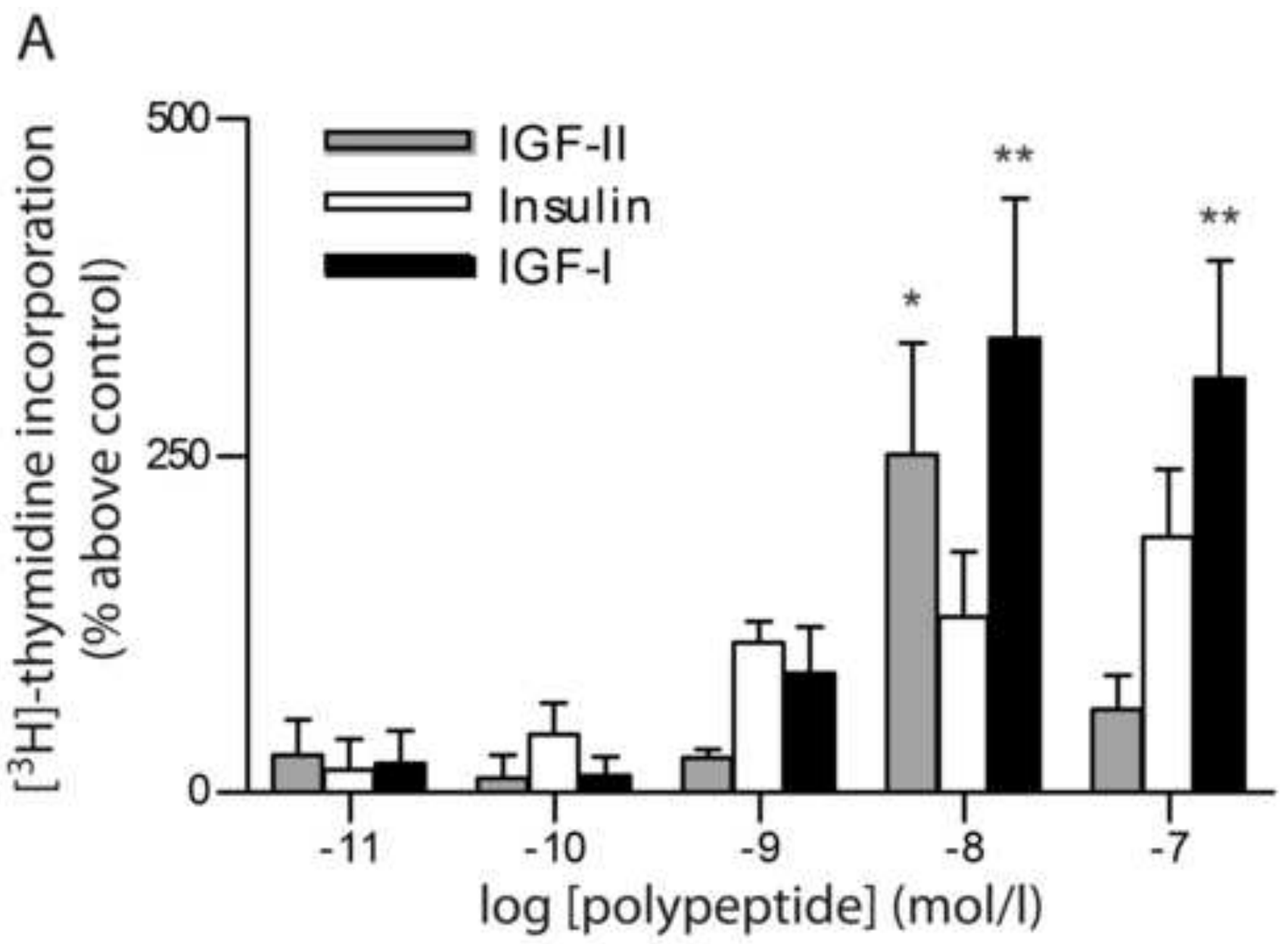

B

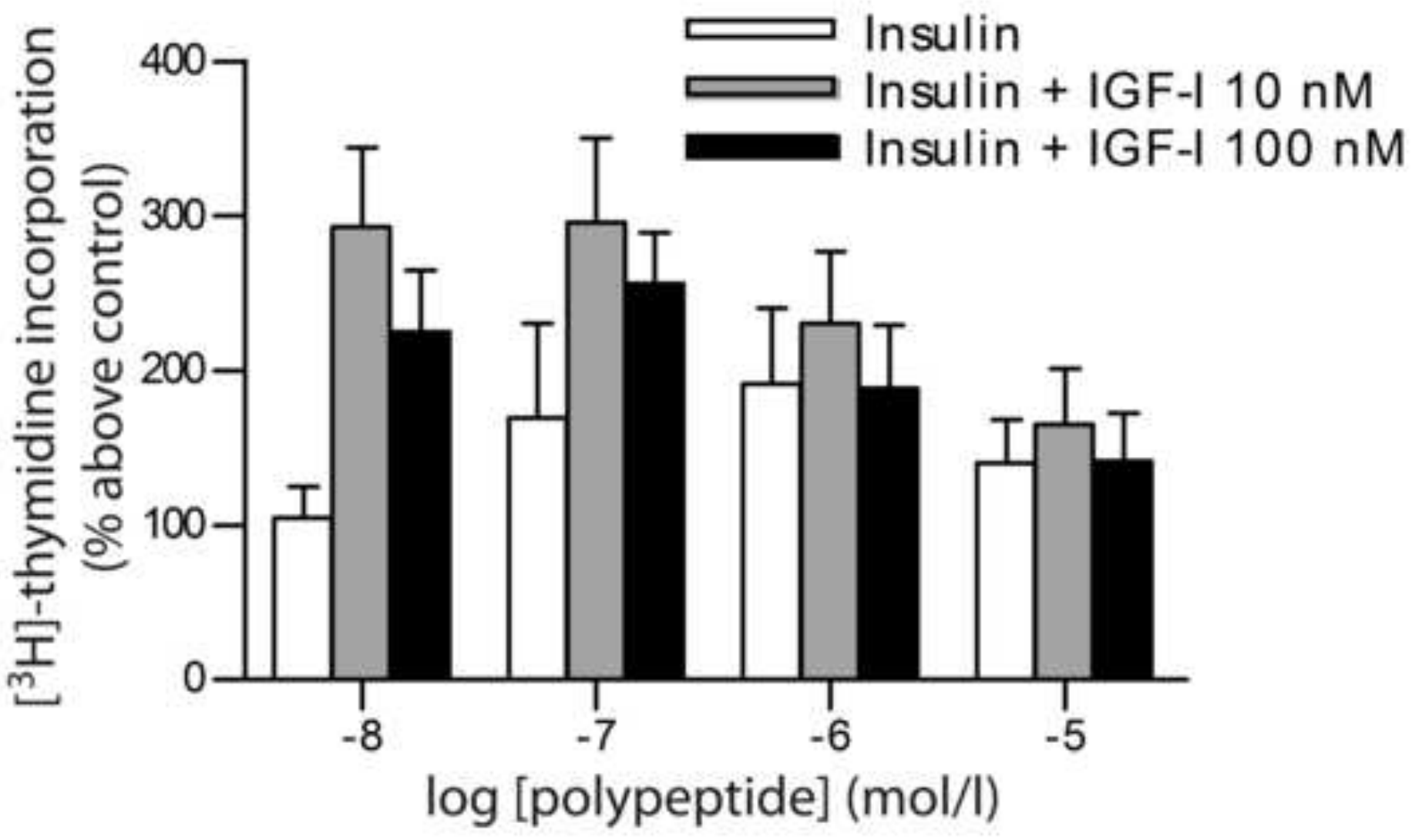




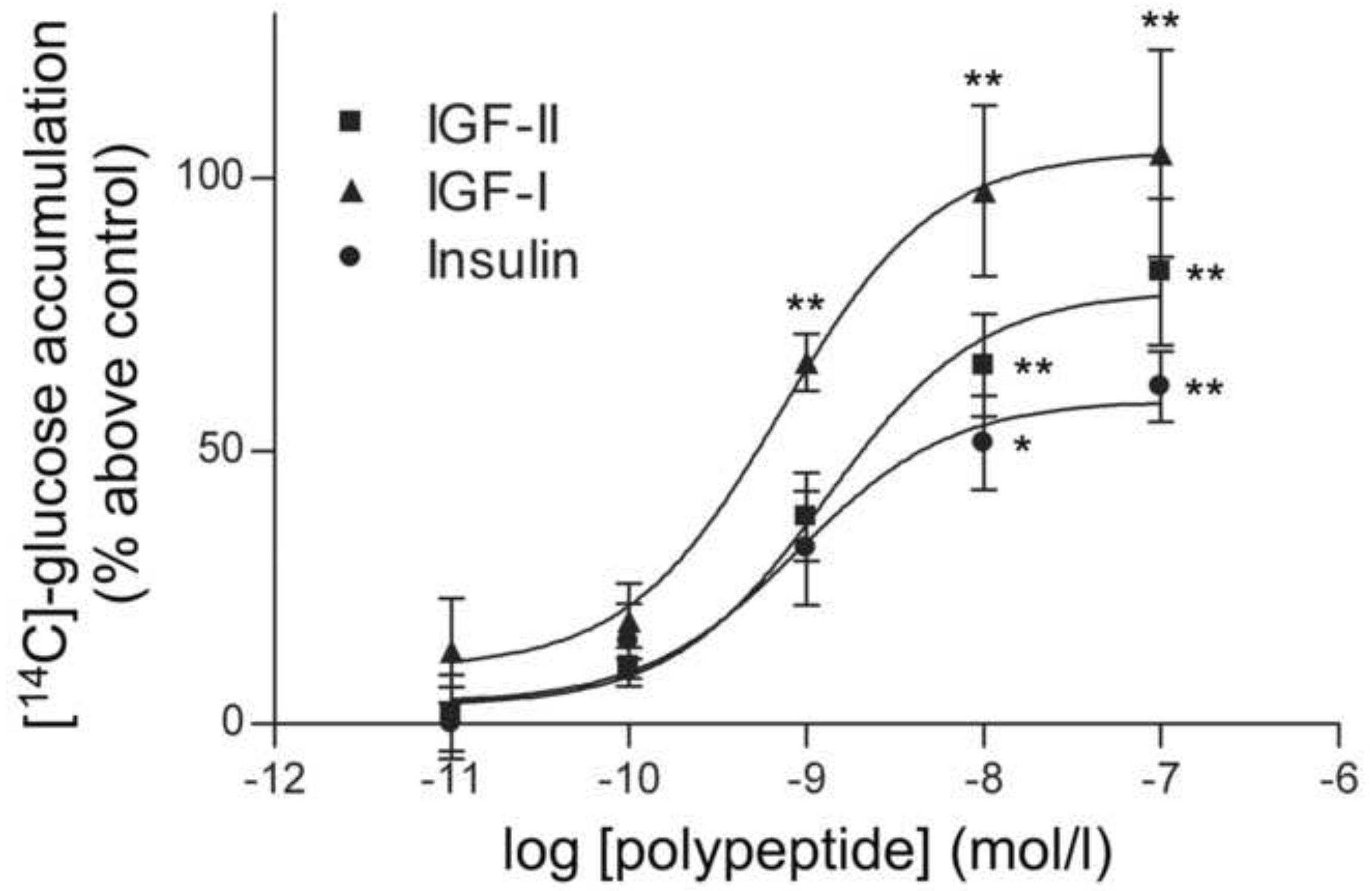

Page 26 of 28 
A
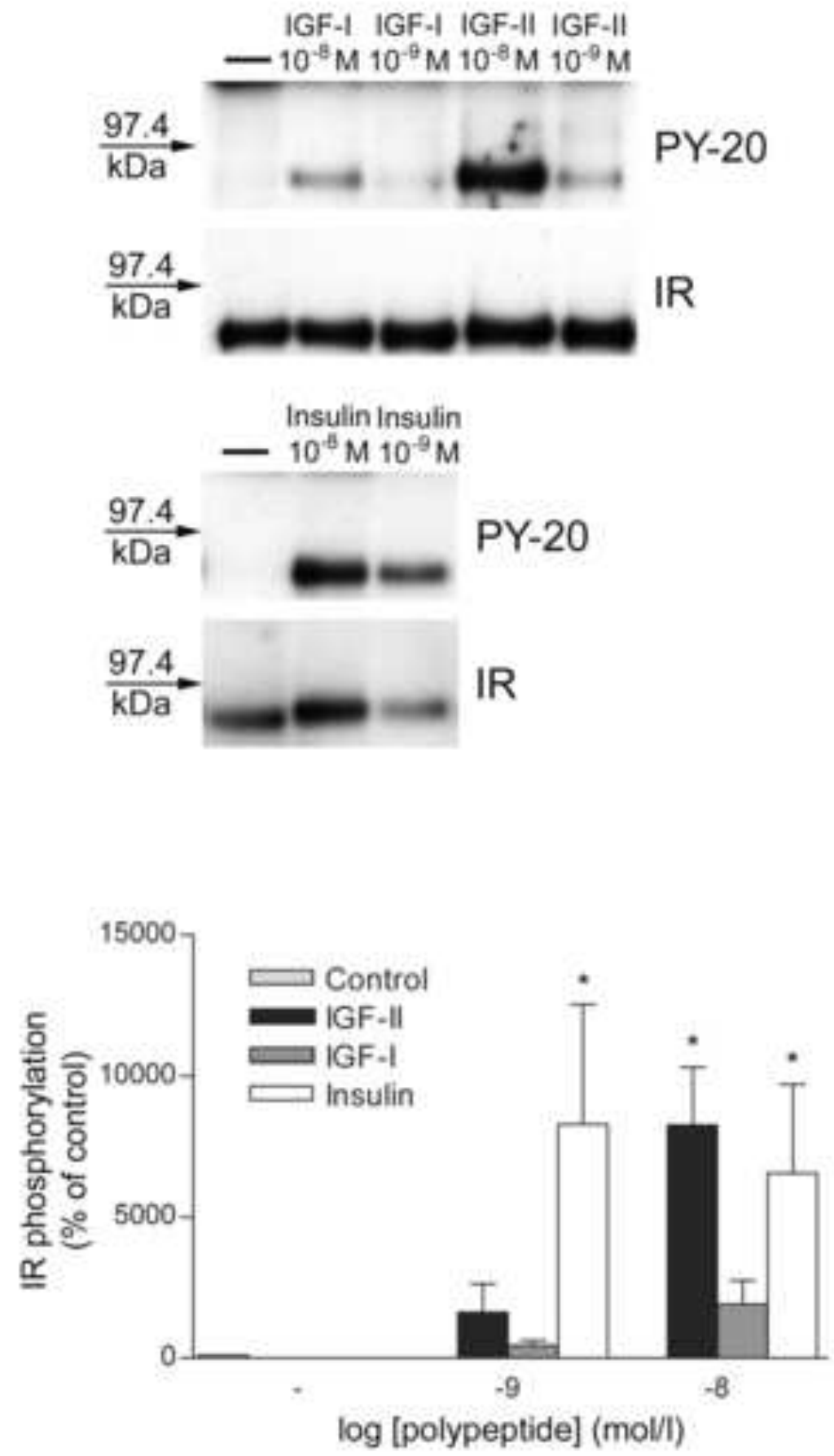

C

IGF-I IGF-11

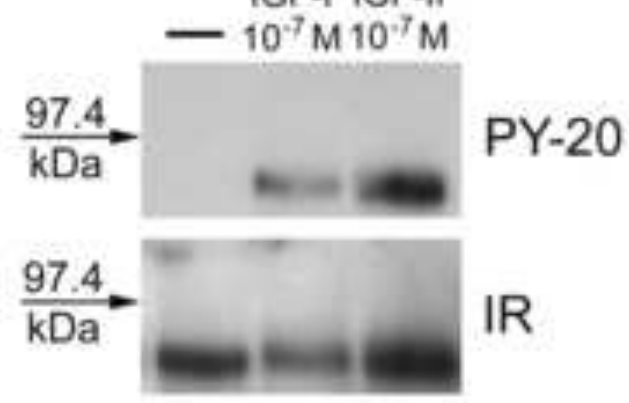


